\title{
PLANOWANIE RUCHU MOBILNEGO ROBOTA KOLOWEGO Z ZASTOSOWANIEM ALGORYTMÓW Z LOGIKĄ ROZMYTĄ
}

\begin{abstract}
W artykule zaprezentowano hierarchiczny układ sterowania ruchem mobilnego robota kołowego w nieznanym środowisku ze statycznymi przeszkodami. Układ sterowania składa się z dwóch warstw, warstwy planowania trajektorii ruchu oraz warstwy realizacji ruchu. Warstwa planowania trajektorii generuje bezkolizyjną trajektorię ruchu robota w złożonym zadaniu typu ,podążaj do celu z omijaniem przeszkód". W warstwie planowania trajektorii ruchu zastosowano metody sztucznej inteligencji w formie układów z logiką rozmytą. Warstwę podrzędną hierarchicznego układu sterowania stanowi neuronowy algorytm sterowania ruchem nadążnym, w którym zastosowano algorytm aproksymacyjnego programowania dynamicznego w konfiguracji dualnego heurystycznego programowania dynamicznego, zrealizowany w formie dwóch struktur: aktora i krytyka. W strukturach aktora i krytyka zastosowano sztuczne sieci neuronowe z wagami warstwy wejściowej dobieranymi w sposób losowy w procesie inicjalizacji sieci i sigmoidalnymi bipolarnymi funkcjami aktywacji neuronów. Poprawności procesu generowania i realizacji trajektorii ruchu zweryfikowano poprzez serię testów numerycznych przeprowadzonych w środowisku obliczeniowym Matlab/Simulink z zastosowaniem emulatora mobilnego robota kołowego oraz toru pomiarowego.
\end{abstract}

Słowa kluczowe: aproksymacyjne programowanie dynamiczne, generator trajektorii, sieci neuronowe, sterowanie nadążne, układy z logiką rozmytą

\section{Wstęp}

Od wielu lat mobilne roboty kołowe (WMR, ang. Wheeled Mobile Robots) cieszą się dużym zainteresowaniem środowisk badawczych oraz szeroko pojętego przemysłu w kontekście możliwości ich implementacji do realizacji specyficznych zadań. Postęp, jaki dokonał się w ciągu ostatnich lat w dziedzinie napędów, układów sensorycznych czy mikroprocesorowych, umożliwił budowę WMR mogących pełnić coraz bardziej złożone zadania usługowe czy transportowe. Jednak nadal istotnymi problemami mobilnej robotyki pozostają kwestie sterowania ruchem oraz generowania w czasie rzeczywistym trajektorii ruchu

\footnotetext{
${ }^{1}$ Autor do korespondencji/corresponding author: Marcin Szuster, Politechnika Rzeszowska, al. Powstańców Warszawy 12, 35-959 Rzeszów, tel.: (17) 865 1854, e-mail: mszuster@prz.edu.pl
} 
WMR. Rozwiązanie tych problemów umożliwia zastosowanie WMR jako jednostek autonomicznych, mogących poruszać się bez nadzoru operatora.

W literaturze można znaleźć wiele metod generowania trajektorii ruchu WMR $[1-4,7,8,12,13,16]$, wśród których można wyróżnić podział na metody lokalne i globalne. W metodach globalnych zakłada się znajomość mapy otoczenia WMR, a trajektoria ruchu może być wygenerowana wcześniej, przed rozpoczęciem ruchu. W metodach lokalnych zakłada się, iż otoczenie WMR pozostaje nieznane, a ograniczona informacja o nim jest dostarczana przez układ sensoryczny robota, który w tym przypadku pełni istotną role $\mathrm{w}$ procesie planowania trajektorii ruchu. Przykładem tego typu metod jest sterowanie behawioralne [3, $7,8]$, którego idea bazuje na obserwacji świata zwierząt i próbie naśladowania ich elementarnych zachowań, takich jak zachowanie typu „omijaj przeszkody” (OA, ang. obstacle avoiding), czy ,podążaj do celu” (GS, ang. goal seeking). Jednakże zastosowanie algorytmu sterowania behawioralnego w zadaniu typu OA czy GS nie gwarantuje poprawnej realizacji złożonego, najczęściej występującego zadania typu ,podążaj do celu z omijaniem przeszkód” (GSOA, ang. goal seeking with obstacle avoiding). Rozwiązanie problemu generowania bezkolizyjnej trajektorii ruchu do celu w nieznanym środowisku $\mathrm{z}$ ominięciem przeszkód przedstawiono w niniejszym artykule.

Zaproponowano hierarchiczny układ sterowania ruchem WMR, w którym zastosowano warstwę planowania trajektorii ruchu w złożonym zadaniu typu GSOA, zrealizowaną z zastosowaniem układów z logiką rozmytą (FLS, ang. Fuzzy Logic System) [7, 8, 18] oraz warstwę realizacji ruchu WMR, zrealizowaną $\mathrm{w}$ formie neuronowego algorytmu sterowania ruchem nadążnym, w którym zastosowano algorytm aproksymacyjnego programowania dynamicznego (ADP, ang. Approximate Dynamic Programming) $[14,15,17]$ w konfiguracji dualnego heurystycznego programowania dynamicznego (DHP, ang. Dual-Heuristic Dynamic Programming). W algorytmie tym struktury aktora i krytyka zrealizowano z zastosowaniem sieci neuronowych (NN, ang. Neural Networks) $[9,10,11]$. Zaprezentowane wyniki badań stanowią kontynuację wcześniejszych prac autora, dotyczących sterowania ruchem nadążnym WMR z zastosowaniem algorytmów ADP [9,10], czy generowania trajektorii ruchu [11, 18, 19].

\section{Mobilny robot kołowy}

Obiektem sterowania jest WMR, którego schemat w nieznanym otoczeniu przedstawiono na rys. 1. WMR składa się z kół napędzających 1 i 2, samonastawnego koła podpierającego 3, ramy 4 oraz skanera laserowego przestrzeni 5. Każde z kół 1 i 2 WMR jest napędzane oddzielnym zespołem napędowym. Skaner laserowy przestrzeni jest elementem układu sensorycznego WMR, umożliwiającym detekcję przeszkód w otoczeniu robota. Założono ruch WMR w płaszczyźnie $x y$ nieruchomego układu odniesienia. 


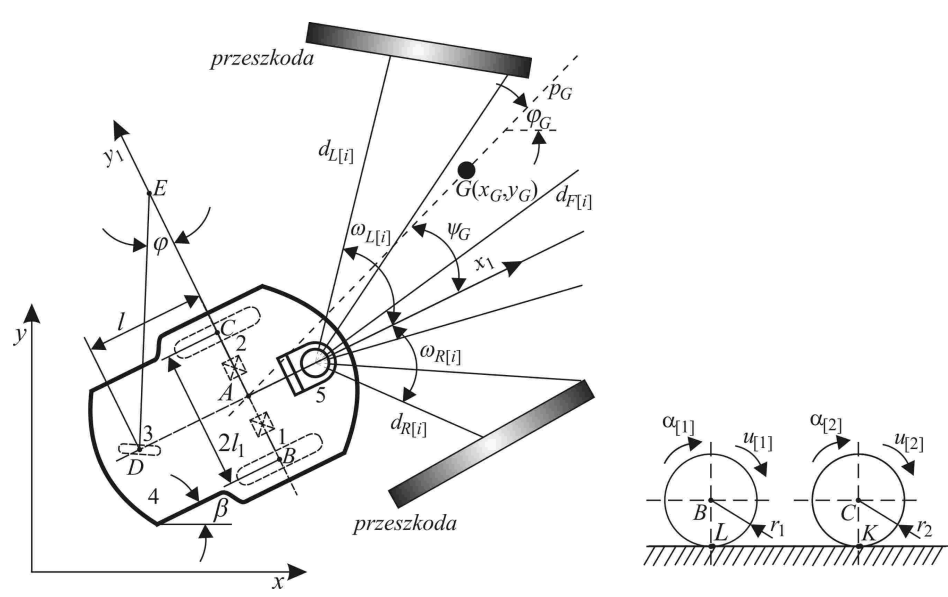

Rys. 1. Schemat mobilnego robota kołowego w nieznanym środowisku

Fig. 1. Scheme of the wheeled mobile robot in the unknown environment

Zastosowano następujące oznaczenia występujące na rys. 1: $\alpha_{[1]}, \alpha_{[2]}-$ kąty obrotu kół napędzających, $u_{[1]}, u_{[2]}$ - sygnały sterowania ruchem nadążnym WMR, $r_{1}=r_{2}=r$ - promienie kół napędzających, $l, l_{1}$ - wymiary wynikające $\mathrm{z}$ geometrii WMR, $\beta$ - kąt obrotu ramy, $A\left(x_{A}, y_{A}\right)$ - punkt leżący na przecięciu osi ramy WMR oraz osi kół napędzających, $G\left(x_{G}, y_{G}\right)$ - zadany cel ruchu WMR, $x_{1}$, $y_{1}$ - osie ruchomego układu współrzędnych powiązanego z p. $A$ w taki sposób, że oś $x_{1}$ jest tożsama z osią symetrii ramy WMR, $p_{G}$ - prosta przechodząca przez punkty $A$ i $G, \psi_{G}$ - kąt zawarty między prostą $p_{G}$, osią $x_{1}, \varphi_{G}$ - kąt zawarty między prostą $p_{G}$ a osią $x$ nieruchomego układu współrzędnych, $d_{L[i]}, d_{F[i]}, d_{R[i]}-$ pomiary odległości do przeszkód realizowane przez układ sensoryczny WMR, wybrane $\mathrm{z}$ wszystkich pomiarów i przyporządkowane grupom pomiarów odległości z lewej strony, przed i z prawej strony ramy WMR, $i=1,2,3, \omega_{L[i]}, \omega_{F[i]}$, $\omega_{R[i]}$ - kąty zawarte między osiami poszczególnych pomiarów a osią $x_{1}$ ruchomego układu współrzędnych. Odległość WMR do celu $d_{G}$ jest wyznaczana jako długość odcinka $d_{G}=|A G|$. W warstwie planowania trajektorii ruchu WMR wyznaczanie wybranych sygnałów sterowania odbywa się na podstawie wartości odległości do przeszkód, przy czym dla poszczególnych grup pomiarów wyznaczana jest wartość minimalna, np. minimalna odległość do przeszkód po prawej stronie ramy WMR wynosi $d_{R m}=\min \left(d_{R[1]}, d_{R[2]}, d_{R[3]}\right)$, analogicznie przed WMR $d_{F m}$, oraz po lewej stronie ramy $d_{L m}$. Minimalna odległość WMR do przeszkód jest wyznaczana zgodnie z zależnością $d_{O}=\min \left(d_{L m}, d_{F m}, d_{R m}\right)$. Dynamiczne równania ruchu WMR otrzymano stosując formalizm Maggie'go $[5,6]$ w postaci zależności:

$$
\mathbf{M} \ddot{\boldsymbol{\alpha}}+\mathbf{C}(\dot{\boldsymbol{\alpha}}) \dot{\boldsymbol{\alpha}}+\mathbf{F}(\dot{\boldsymbol{\alpha}})+\boldsymbol{\tau}_{d}=\mathbf{u},
$$


gdzie: $\dot{\boldsymbol{\alpha}}$ - wektor prędkości kątowych kół napędzających, $\dot{\boldsymbol{\alpha}}=\left[\dot{\alpha}_{[1]}, \dot{\alpha}_{[2]}\right]^{T}, \mathbf{M}-$ stała macierz bezwładności WMR, $\mathbf{C}(\dot{\boldsymbol{\alpha}}) \dot{\boldsymbol{\alpha}}$ - wektor momentów pochodzących od sił odśrodkowych i Coriolisa, $\mathbf{F}(\dot{\boldsymbol{\alpha}})$ - wektor oporów ruchu, $\boldsymbol{\tau}_{d}$ - wektor ograniczonych zakłóceń, $\mathbf{u}$ - wektory sygnałów sterowania, $\mathbf{u}=\left[u_{[1]}, u_{[2]}\right]^{T}$.

Ponieważ w układzie sterowania zastosowano algorytmy działające w dyskretnej dziedzinie czasu, model ciągły (1) zdyskretyzowano z zastosowaniem metody Eulera, przyjmując wektor stanu $\mathbf{z}_{\{k\}}=\left[\mathbf{z}_{1\{k\}}, \mathbf{z}_{2\{k\}}\right]^{T}$, gdzie $\mathbf{z}_{2\{k\}}$ odpowiada wektorowi $\dot{\boldsymbol{\alpha}} \mathrm{w}$ ciągłej dziedzinie czasu. Otrzymano dyskretny opis dynamiki WMR w formie:

$$
\begin{gathered}
\mathbf{z}_{1\{k+1\}}=\mathbf{z}_{1\{k\}}+h \mathbf{z}_{2\{k\}}, \\
\mathbf{z}_{2\{k+1\}}=\mathbf{z}_{2\{k\}}-h \mathbf{M}^{-1}\left[\mathbf{C}\left(\mathbf{z}_{2\{k\}}\right) \mathbf{z}_{2\{k\}}+\mathbf{F}\left(\mathbf{z}_{2\{k\}}\right)+\boldsymbol{\tau}_{d\{k\}}-\mathbf{u}_{\{k\}}\right],
\end{gathered}
$$

gdzie: $h$ - parametr dyskretyzacji czasu, $k$ - indeks kroków iteracji. W dalszej części artykułu wszystkie zmienne będą przedstawiane w postaci dyskretnej.

\section{Hierarchiczny układ sterowania}

Sterowanie ruchem WMR odbywa się z zastosowaniem hierarchicznego układu sterowania, złożonego z warstwy planowania trajektorii ruchu, oraz warstwy realizacji ruchu. Zadaniem warstwy planowania ruchu jest generowanie w czasie ruchu zadanych parametrów ruchu WMR na podstawie znajomości położenia i orientacji ramy WMR, położenia celu oraz odległości do przeszkód. Generowana trajektoria ruchu jest realizowana przez niższą warstwę sterowania zrealizowaną $\mathrm{w}$ formie algorytmu sterowania nadążnego. W prezentowanym układzie sterowania, w realizacji warstwy planowania ruchu WMR, zastosowano ideę sterowania behawioralnego w zadaniach typu OA i GS oraz rozmyty koordynator sterowań behawioralnych, którego zastosowanie umożliwia realizację złożonego zadania typu GSOA. Generowanie sygnałów sterowania behawioralnego w zadaniach typu GS i OA również odbywa się z zastosowaniem FLS. W warstwie realizacji ruchu zastosowano neuronowy układ sterowania nadążnego, zrealizowany z zastosowaniem algorytmu ADP w konfiguracji DHP. Schemat hierarchicznego układu sterowania przedstawiono na rys. 2. Szczegółowy opis poszczególnych warstw hierarchicznego układu sterowania, wraz z wyjaśnieniem symboli występujących na rys. 2 przedstawiono w kolejnych podrozdziałach. 


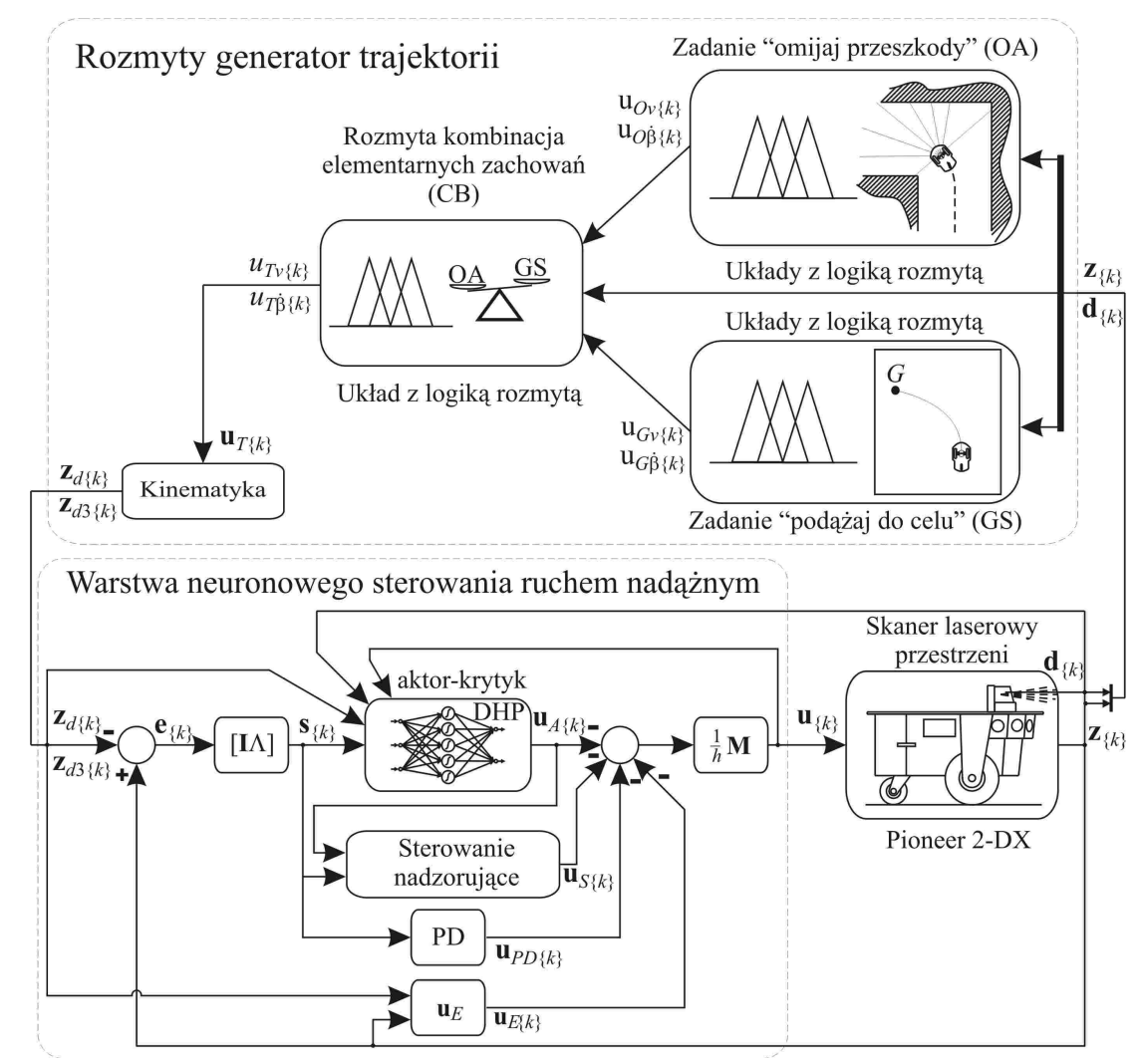

Rys. 2. Schemat hierarchicznego układu sterowania ruchem mobilnego robota kołowego w zadaniu typu ,podążaj do celu z omijaniem przeszkód”

Fig. 2. Scheme of the hierarchical control system of the wheeled mobile robot in the "goal seeking and obstacle avoiding" task

\subsection{Warstwa planowania trajektorii ruchu}

Warstwa planowania trajektorii ruchu umożliwia generowanie bezkolizyjnej trajektorii ruchu WMR w nieznanym środowisku 2D ze statycznymi przeszkodami. Realizowane jest złożone zadanie typu GSOA, będące połączeniem realizacji dwóch prostych zachowań, typu OA i GS. Realizacja zadania typu OA polega na wygenerowaniu sterowań behawioralnych, przeliczanych z zastosowaniem równań kinematyki WMR na zadaną trajektorię ruchu, które umożliwią bezkolizyjny ruch WMR, przy czym położenie celu ruchu nie jest zdefiniowane. Wyznaczanie bezkolizyjnej trajektorii ruchu odbywa się na podstawie informacji o lokalizacji przeszkód wokół WMR, dostarczonych z układu sensorycznego robota. Realizacja zadania typu GS polega na wygenerowaniu sygnałów sterowania behawioralnego, umożliwiających ruch WMR z aktualnie zajmowanej pozycji do zadanego celu, przy czym położenie przeszkód nie jest brane pod 
uwagę przy planowaniu trajektorii. Schematycznie realizację zadania typu OA przedstawiono na rys. 3.a), realizację zadania typu GS na rys. 3.b).

a)

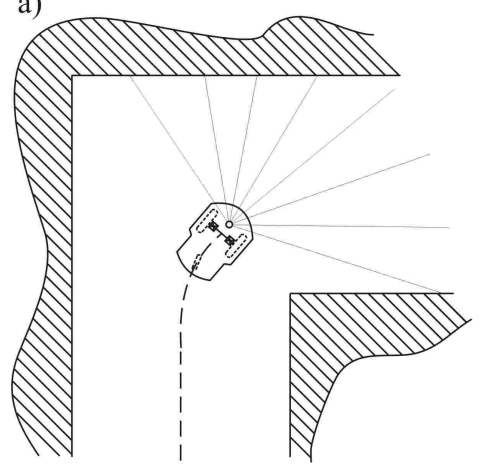

b)

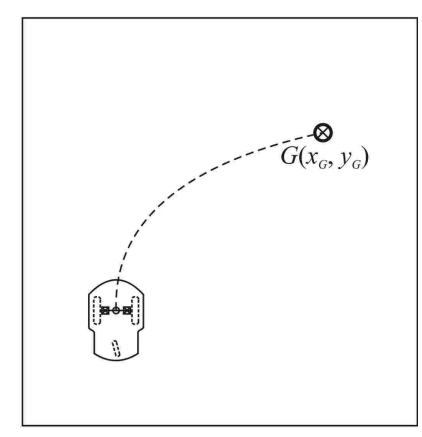

Rys. 3. a) Schemat realizacji zadania typu „omijaj przeszkody”, b) schemat realizacji zadania typu ,podążaj do celu"

Fig. 3. a) Scheme of the "obstacle avoiding" task realisation, b) scheme of the "goal seeking" task realisation

Realizacja warstwy planowania ruchu z zastosowaniem sterowania behawioralnego dla jednego z wymienionych zadań nie umożliwia realizacji bezkolizyjnego ruchu do zadanego celu w każdym przypadku. Realizacja złożonego zadania typu GSOA wymaga zastosowania połączenia sterowania behawioralnych dla zadań typu OA i GS w odpowiednich proporcjach. Koordynacja sterowań behawioralnych zadań typu OA i GS może być realizowana w różny sposób, stosując stałą wartość współczynnika udziału poszczególnych sterowań behawioralnych $w$ wynikowych sygnałach sterowania lub zmieniając udział poszczególnych zachowań w zależności od warunków środowiska. Zastosowanie stałej wartości współczynnika koordynacji sterowań behawioralnych wymaga przeprowadzenia szeregu eksperymentów lub testów numerycznych w celu jego heurystycznego doboru i nie zawsze gwarantuje poprawną realizację zadania typu GSOA. Odpowiednim podejściem wydaje się być uzależnienie udziału wartości poszczególnych sygnałów sterowania behawioralnego od warunków środowiska i zastosowanie współczynnika koordynacji o zmiennej wartości, generowanego przez dodatkowy algorytm sterujący warstwy planowania trajektorii ruchu. W prezentowanym artykule do realizacji tego zadania zastosowano FLS, generujący sygnał koordynujący sterowania behawioralne na podstawie odległości do celu i przeszkód.

\subsubsection{Sterowanie behawioralne typu ,omijaj przeszkody”}

Układ sterowania behawioralnego w zadaniu typu OA został zrealizowany z zastosowaniem dwóch FLS, w których zastosowano model Takagi-Sugeno z trójkątnymi bądź trapezowymi funkcjami przynależności do zbiorów rozmy- 
tych przesłanek oraz funkcjami przynależności typu singleton w konkluzjach. Pierwszy z FLS generuje sygnał $u_{O v\{k\}}$ sterujący zadaną prędkością p. $A$ ramy na podstawie odległości do przeszkód $d_{O\{k\}}$. Gdy WMR znajduje się w „dużej” odległości do przeszkód, generowana jest trajektoria ruchu z maksymalną zadaną prędkością $v_{A}^{*}$, gdy odległość do przeszkód jest „mała”, generowana jest trajektoria ruchu $\mathrm{z}$ odpowiednio mniejszą prędkością, umożliwiającą realizację manewru ominięcia przeszkody. Drugi z FLS generuje sygnał sterowania behawioralnego $u_{O \dot{\beta}\{k\}}$, sterujący zadaną prędkością kątową obrotu ramy WMR w taki sposób, aby minimalizowana była wartość błędu:

$$
e_{O\{k\}}=d_{R\{k\}}^{*}-d_{L\{k\}}^{*},
$$

gdzie: $d_{L\{k\}}^{*}, d_{R\{k\}}^{*}$ - znormalizowane minimalne odległości do przeszkód po lewej i prawej stronie ramy WMR, $d_{L m\{k\}}$ i $d_{R m\{k\}}$. Minimalizacja błędu (3) powoduje generowanie trajektorii ruchu WMR środkiem wolnej przestrzeni. Algorytm sterowania behawioralnego w zadaniu typu OA opisano w [19].

\subsubsection{Sterowanie behawioralne typu ,podążaj do celu”}

Układ sterowania behawioralnego w zadaniu typu GS został zrealizowany z zastosowaniem dwóch FLS, w których zastosowano model Takagi-Sugeno z trójkątnymi bądź trapezowymi funkcjami przynależności do zbiorów rozmytych przesłanek, oraz funkcjami przynależności typu singleton w konkluzjach. Pierwszy FLS generuje sygnał $u_{G v\{k\}}$ sterujący zadaną prędkością p. $A$ ramy WMR na podstawie odległości do celu $G, d_{G\{k\}}$. Gdy robot znajduje się w „dużej” odległości do celu, generowana jest trajektoria ruchu z maksymalną zadaną prędkością $v_{A}^{*}$, gdy WMR zbliża się do celu, wartość sygnału sterowania jest redukowana, umożliwiając zatrzymanie ramy w zadanym położeniu. Drugi FLS generuje sygnał sterowania behawioralnego $u_{G \dot{\beta}\{k\}}$, sterujący zadaną prędkością kątową obrotu ramy WMR w taki sposób, aby zminimalizować wartość kąta $\psi_{G\{k\}}$. Minimalizacja kąta $\psi_{G\{k\}}$ powoduje ruch ramy WMR w kierunku celu $G$. Algorytm sterowania behawioralnego w zadaniu typu GS opisano w [19].

\subsubsection{Rozmyta koordynacja sterowań behawioralnych}

Rozmyty koordynator sterowań behawioralnych umożliwia miękkie przełączanie realizowanych zadań typu OA i GS w trakcie realizacji złożonego zadania typu GSOA. Wynikowy sygnał sterowania warstwy generowania trajektorii ruchu $\mathbf{u}_{T\{k\}}=\left[u_{T v\{k\}}, u_{T \dot{\beta}\{k\}}\right]^{T}$ jest kombinacją sygnałów sterowania behawioralnego typu OA, $\mathbf{u}_{O\{k\}}=\left[u_{O v\{k\}}, u_{O \dot{\beta}\{k\}}\right]^{T}$ oraz sterowania behawioralnego typu GS, $\mathbf{u}_{G\{k\}}=\left[u_{G v\{k\}}, u_{G \dot{\beta}\{k\}}\right]^{T}$, zgodnie z zależnością: 


$$
\mathbf{u}_{T\{k\}}=a_{B\{k\}} \mathbf{u}_{G\{k\}}+\left(1-a_{B\{k\}}\right) \mathbf{u}_{O\{k\}},
$$

gdzie: $a_{B\{k\}}$ - sygnał sterujący rozmytego koordynatora sterowań, zrealizowanego z zastosowaniem FLS. Na podstawie sygnałów sterujących wyznaczonych stosując zależność (4), obliczane są zadane prędkości kątowe obrotu kół WMR zgodnie z zależnością

$$
\left[\begin{array}{c}
z_{d 2[1]\{k\}} \\
z_{d 2[2]\{k\}}
\end{array}\right]=\frac{1}{r}\left[\begin{array}{cc}
v_{A}^{*} & l_{1} \dot{\beta}^{*} \\
v_{A}^{*} & -l_{1} \dot{\beta}^{*}
\end{array}\right]\left[\begin{array}{l}
u_{T v\{k\}} \\
u_{T \dot{\beta}\{k\}}
\end{array}\right],
$$

gdzie: $\dot{\beta}^{*}$ - maksymalna zadana prędkość kątowa obrotu ramy WMR.

Sygnał koordynujący udział poszczególnych sterowań behawioralnych $a_{B\{k\}}$ jest generowany przez FLS na podstawie wartości dwóch sygnałów, znormalizowanej odległości do celu $d_{G\{k\}}^{*}$ oraz znormalizowane odległości do przeszkód $d_{O\{k\}}^{*}$. Do jego realizacji zastosowano model Takagi-Sugeno z trójkątnymi lub trapezowymi funkcjami przynależności do zbiorów rozmytych przesłanek i konkluzji oraz bazą $m=25$ reguł typu:

$$
R^{m}: \text { JEŻELI } d_{G\{k\}}^{*} \text { JEST } d B M \text { I } d_{O\{k\}}^{*} \text { JEST } l D \text { TO } a_{B\{k\}} \text { JEST } u B D 1,
$$

gdzie: $d B M, l D, u B D 1$ - lingwistyczne etykiety funkcji przynależności do zbiorów rozmytych przesłanek i konkluzji, $B M O$ - „bardzo mały, bliski 0”, $B M-$ „,bardzo mały”, $M-$ „,mały”, $S$ - ,średni”, $D$ - „duży”, $B D$ - „,bardzo duży”, $B D 1$ - ,bardzo duży, bliski 1'”.

Funkcje przynależności do zbiorów rozmytych przesłanek przedstawiono na rys. 4.a) i b) odpowiednio dla pierwszego i drugiego wejścia, natomiast funkcje przynależności do zbiorów rozmytych konkluzji, typu singleton, przyjmują wartości $a B D M 0=0, a B M=0.1, A M=0.35, A s=0.6, A d=0.75, a B D=0.9$, $a B D 1=1$. Przestrzenie wejść do FLS podzielono na 5 zbiorów trójkątnych i trapezowych, natomiast w konkluzjach zastosowano 7 funkcji przynależności. Schemat bazy reguł FLS przedstawiono na rys. 5. Otrzymano powierzchnię modelu rozmytego przedstawioną na rys. 6 .

Z zastosowanej bazy reguł wynika, że jeżeli WMR znajduje się w pobliżu celu, w generowanej trajektorii ruchu dominujący udział ma zachowanie typu GS. Gdy WMR znajduje się w pobliżu przeszkód, dominujący udział ma zachowanie typu OA, natomiast $\mathrm{w}$ pozostałych przypadkach wynikowe zachowanie jest połączeniem zachowań typu OA i GS w odpowiednich proporcjach, wynikających z przyjętej bazy reguł, gdzie położenia funkcji przynależności do zbiorów rozmytych dobrano heurystycznie. Zastosowanie koordynacji sterowań behawio- 
ralnych o zmiennym udziale poszczególnych zadań umożliwia realizację zadania typu GSOA.
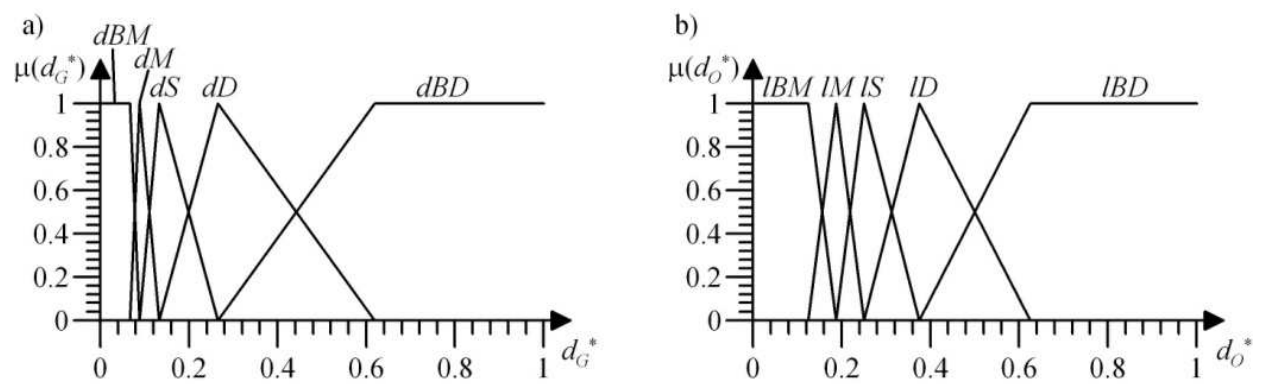

Rys. 4. a) Funkcje przynależności do zbiorów rozmytych przesłanek wartości $d_{G}^{*}$, b) funkcje przynależności do zbiorów rozmytych przesłanek wartości $d_{O}^{*}$

Fig. 4. a) Membership functions of premises of $d_{G}^{*}$ value, b) membership functions of premises of $d_{o}^{*}$ value

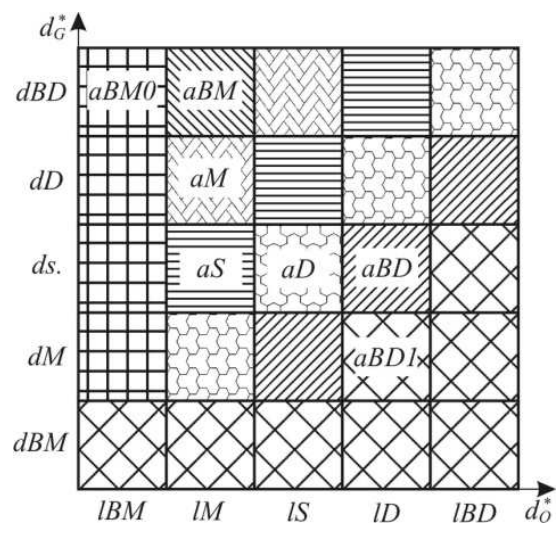

Rys. 5. Schemat bazy reguł układu z logiką rozmytą

Fig. 5. Scheme of the rules base of the fuzzy logic system

\subsection{Warstwa realizacji ruchu}

Warstwa realizacji ruchu generuje sygnały sterujące $\mathbf{u}_{\{k\}}$ układami napędowymi, umożliwiające ruch p. A ramy WMR po wyznaczonym torze ruchu, zachowując zadaną orientację ramy. $\mathrm{Na}$ podstawie zadanych $\left(\mathbf{z}_{d\{k\}}\right)$ i zrealizowanych $\left(\mathbf{z}_{d\{k\}}\right)$ parametrów ruchu wyznaczono błędy nadążania
Rys. 6. Powierzchnia modelu rozmytego

Fig. 6. Surface of the fuzzy logic model 


$$
\begin{aligned}
\mathbf{e}_{1\{k\}} & =\mathbf{z}_{1\{k\}}-\mathbf{z}_{d 1\{k\}}, \\
\mathbf{e}_{2\{k\}} & =\mathbf{z}_{2\{k\}}-\mathbf{z}_{d 2\{k\},}
\end{aligned}
$$

a na ich podstawie uogólnione błędy nadążania, minimalizowane przez algorytm realizacji ruchu:

$$
\mathbf{s}_{\{k\}}=\mathbf{e}_{2\{k\}}+\Lambda \mathbf{e}_{1\{k\}},
$$

gdzie: $\Lambda$ - diagonalna, stała, dodatnio określona macierz projektowa.

W warstwie realizacji ruchu zastosowano algorytm ADP [14, 15, 17] w konfiguracji DHP. Składa się on ze struktur aktora, krytyka oraz modelu predykcyjnego sterowanego obiektu. Struktury aktora i krytyka zrealizowano z zastosowaniem NN Random Vector Functional Link (RVFL). Zarówno aktor, jak i krytyk składają się z dwóch SN RVFL liniowych ze względu na wagi warstwy wyjściowej, o stałych wartościach wag warstwy wejściowej dobieranych losowo $\mathrm{w}$ procesie inicjalizacji oraz sigmoidalnych bipolarnych funkcjach aktywacji neuronów. W każdej z NN zastosowano 8 neuronów.

Warstwa sterowania ruchem nadążnym WMR składa się z algorytmu ADP w konfiguracji DHP, generującego sygnał sterowania $\mathbf{u}_{A\{k\}}$, regulatora PD o sygnale sterowania $\mathbf{u}_{P D\{k\}}$ oraz dodatkowych elementów układu sterowania takich jak człon sterowania nadzorującego oraz dodatkowy sygnał sterowania $\mathbf{u}_{E\{k\}}$. Człon sterowania nadzorującego o strukturze wynikającej z analizy stabilności zamkniętego układu sterowania ruchem nadążnym, przeprowadzonej $\mathrm{z}$ zastosowaniem teorii stabilności Lyapunov'a, generuje sygnał sterowania $\mathbf{u}_{S\{k\}}$, zapewniający stabilność zamkniętego układu sterowania. Dodatkowy sygnał sterowania $\mathbf{u}_{E\{k\}}$ ma strukturę wynikającą z procesu dyskretyzacji ciągłego opisu układu zamkniętego. Zadaniem regulator PD jest m.in. generowanie sygnału sterowania ruchem nadążnym $\mathrm{w}$ początkowym etapie ruchu WMR, w przypadku gdy proces adaptacji wag NN struktury kompensującej nieliniowości sterowanego obiektu dopiero się rozpoczął. Całkowity sygnał sterowania ruchem nadążnym WMR przyjęto $\mathrm{w}$ formie

$$
\mathbf{u}_{\{k\}}=-\frac{1}{h} \mathbf{M}\left[\mathbf{u}_{A\{k\}}+\mathbf{u}_{P D\{k\}}+\mathbf{u}_{S\{k\}}+\mathbf{u}_{E\{k\}}\right],
$$

gdzie:

$$
\begin{gathered}
\mathbf{u}_{P D\{k\}}=\mathbf{K}_{D} \mathbf{s}_{\{k\}}, \\
\mathbf{u}_{S\{k\}}=\mathbf{I}_{S} \mathbf{u}_{S\{k\}}^{*}, \\
\mathbf{u}_{E\{k\}}=h\left[\Lambda \mathbf{e}_{2\{k\}}-\mathbf{z}_{d 3\{k\}}\right],
\end{gathered}
$$


gdzie: $\mathbf{K}_{D}$ - dodatnio określona, diagonalna macierz współczynników wzmocnień regulatora $\mathrm{PD}, \mathbf{u}_{S\{k\}}^{*}$ - wektor sygnałów sterowania nadzorującego, $\mathbf{I}_{S}$ - macierz diagonalna o współczynnikach $I_{S[j, j]}=1$, gdy $\left|s_{[j]\{k\}}\right| \geq \rho_{[j]}$, lub $I_{S[j, j]}=0 \mathrm{w}$ przeciwnym przypadku, $j=1,2, \rho_{[j]}$ - stała wartość projektowa.

Algorytm sterowania ruchem nadążnym WMR szczegółowo opisano w $[9,10]$.

\section{Wyniki testów numerycznych}

Testy numeryczne hierarchicznego układu sterowania przeprowadzono w środowisku obliczeniowym Matlab/Simulink. Zamodelowano dynamiczne równania ruchu WMR, zasymulowano działanie układu sensorycznego robota, zrealizowanego $\mathrm{w}$ formie laserowego skaner przestrzeni, oraz zaprogramowano model laboratoryjnego środowiska pomiarowego. Przygotowane algorytmy symulacji umożliwiły modelowanie ruchu WMR oraz jego interakcji ze środowiskiem realizowanej z zastosowaniem układu sensorycznego. W ramach testów numerycznych przeprowadzono symulację działania hierarchicznego układu sterowania ruchem WMR w złożonym zadaniu typu GSOA. W celu uproszczenia zapisu zmiennych, w dalszej części artykułu zrezygnowano z zamieszczania indeksu $k$ w oznaczeniach zmiennych, w testach numerycznych stosowano krok dyskretyzacji czasu o wartości $h=0.01$ [s]. Przeprowadzono testy numeryczne ruchu WMR w symulowanym torze pomiarowym, z położenia początkowego $\mathrm{w}$ punkcie $S(0.6,0.95)$, oznaczonego trójkątem na rys. 7 , do celu oznaczonego znakiem ,X”, zlokalizowanego w punktach: $G_{A}(4.8,3.5), G_{B}(9.3,3.5), G_{C}(7.0$, 1.5). Tor ruchu p. A MRK, oznaczony linią ciągłą, wraz z mapą otoczenia przedstawiono na rys. 7.a), b) i c) odpowiednio dla poszczególnych lokalizacji celu. Szarymi kropkami oznaczono położenia przeszkód zlokalizowane przez zamodelowany układ sensoryczny WMR. Liniami przerywanymi zaznaczono osie wybranych pomiarów zrealizowanych przez układ sensoryczny WMR w chwilach czasu $t=0[\mathrm{~s}], t=14[\mathrm{~s}]$ i $t=28[\mathrm{~s}]$.

Realizacja zadania typu GSOA była uznawana za poprawną, jeżeli po zakończonym ruchu WMR odległość do celu $d_{G} \leq 0.03[\mathrm{~m}]$. Przeprowadzone testy numeryczne potwierdziły poprawność procesu generowania bezkolizyjnej trajektorii ruchu MRK w nieznanym środowisku. Poniżej szczegółowo przedstawiono wyniki otrzymane w trakcie symulacji ruchu WMR do celu $G_{B}(9.3,3.5)$.

Przebieg wartości odległości do celu $d_{G}$ przedstawiono na rys. 8.a). Odległość do celu zmniejsza się w czasie ruchu WMR do zakładanej wartości $d_{G} \leq$ $0.03[\mathrm{~m}]$. Na rys. 8.b) przedstawiono przebieg wartości kąta $\psi_{G}$, którego wartość zmienia się w trakcie ruchu robota ze względu na orientację ramy WMR. Można zauważyć, że w końcowym etapie ruchu, gdy $t>25$ [s], wartość kąta $\psi_{G}$ jest bliska zero, co oznacza, że WMR porusza się w kierunku celu po torze ruchu zbliżonym do prostoliniowego. 

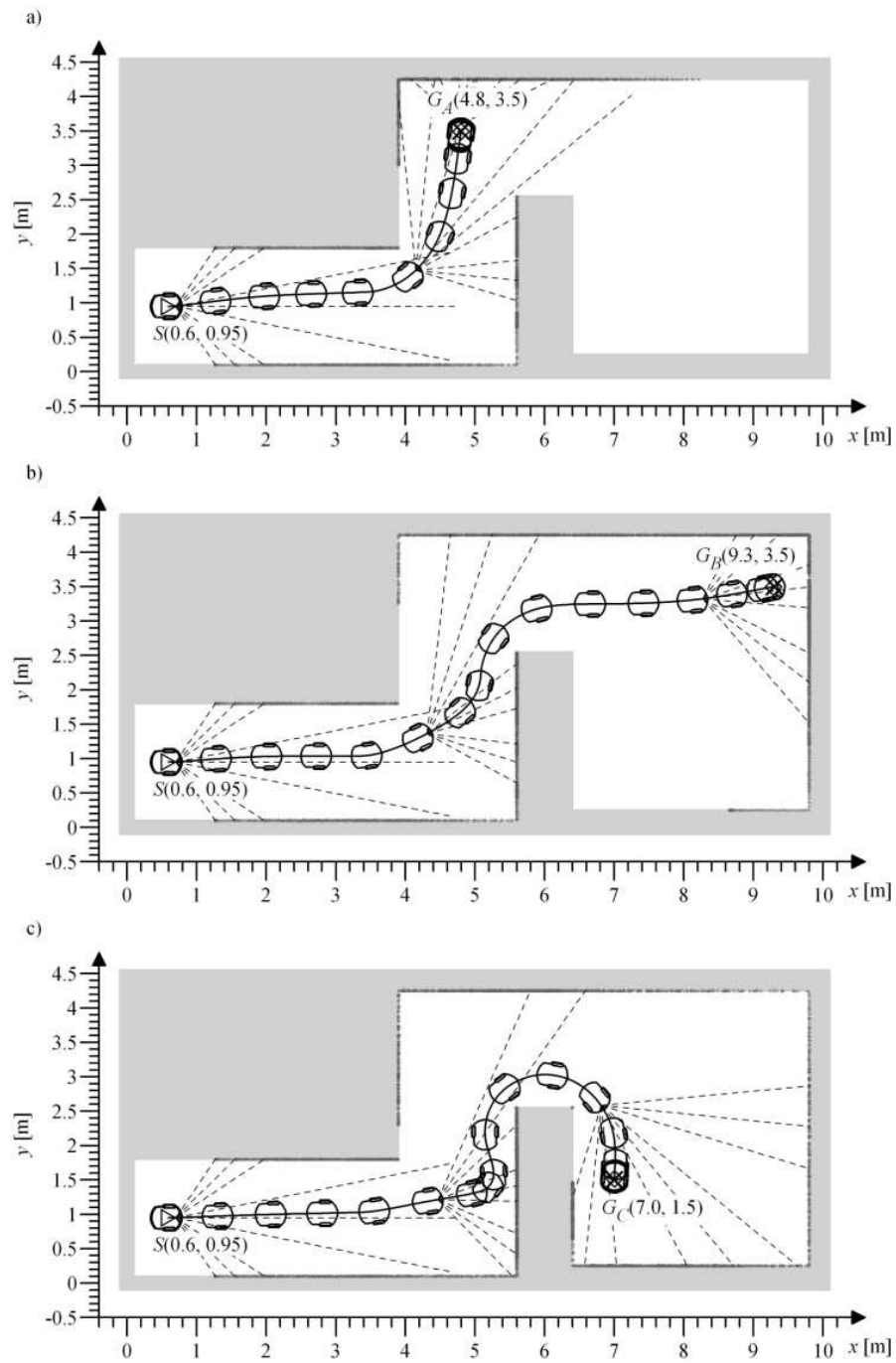

Rys. 7. Mapa symulowanego środowiska pomiarowego w zadaniu typu ,podążaj do celu z omijaniem przeszkód" w ruchu do celu: a) $G_{A}(4,8 ; 3,5)$, b) $G_{B}(9,3 ; 3,5)$, c) $G_{C}(7,0 ; 1,5)$

Fig. 7. Map of the simulated environment in the ,goal seeking and obstacle avoiding" task in moving to the goal: a) $G_{A}(4.8,3.5)$, b) $G_{B}(9.3,3.5)$, c) $G_{C}(7.0,1.5)$

Przebieg wartości sygnału koordynującego udział poszczególnych sterowań behawioralnych $a_{B}$ przedstawiono na rys. 9.a. Przebieg wartości wynikowych sygnałów sterowania warstwy generowania bezkolizyjnej trajektorii ruchu $u_{T v} \mathrm{i}$ $u_{T \dot{\beta}}$ przedstawiono na rys. 9.b. Sygnały te, zgodnie z zależnością (4), mają wartości wyznaczane na podstawie behawioralnych sygnałów sterowania dla zadań 
typu OA (rys. 9.c) i GS (rys. 9.d). Wartość sygnału koordynacji zachowań $a_{B}$ zmienia się $\mathrm{w}$ zależności od odległości do celu i przeszkód, przykładowo w czasie $t_{1} \in\langle 15,18.5\rangle$ [s] WMR zbliża się do przeszkody, wartość sygnał $a_{B}$ maleje, co zwiększa wpływ sterowań behawioralnych typu OA w wynikowych sygnałach sterowania warstwy generowania trajektorii ruchu.
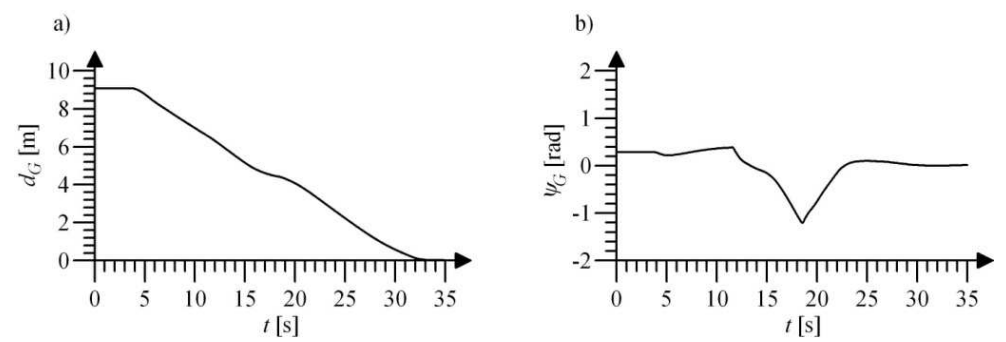

Rys. 8. a) Odległość do celu $d_{G}$, b) wartość kąta $\psi_{G}$

Fig. 8. a) Distance to the goal $d_{G}$, b) value of the $\psi_{G}$ angle
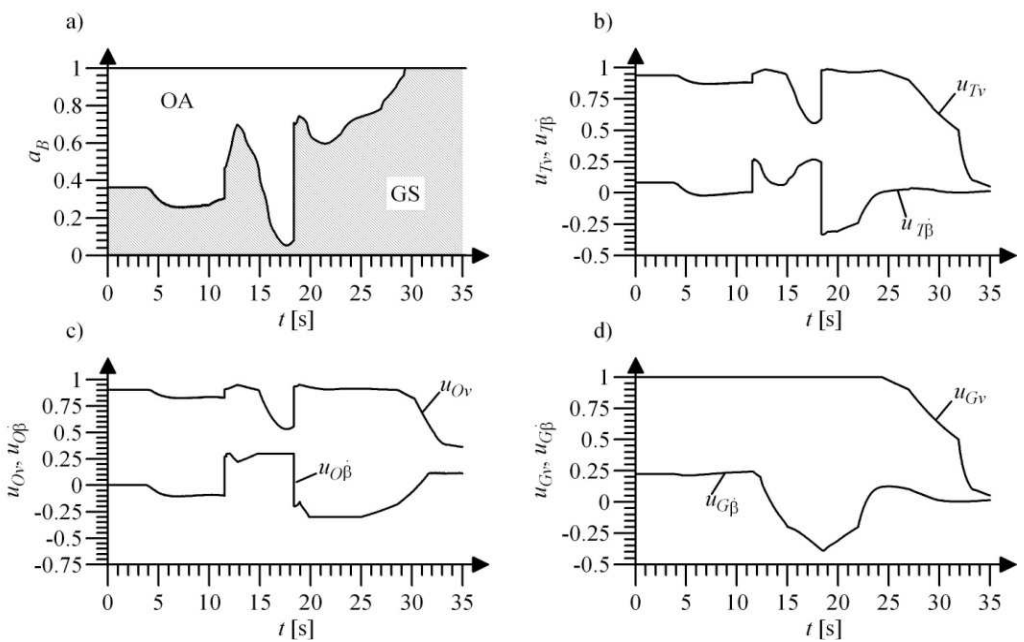

Rys. 9. a) Sygnał $a_{B}$, b) sygnały sterowania warstwy generowania trajektorii $u_{T v}$ i $u_{T \dot{\beta}}$, c) sygnały $u_{O v}$ i $u_{O \dot{\beta}}$ układu sterowania realizującego zadanie typu „omijaj przeszkody”, d) sygnały $u_{G v}$ i $u_{G \dot{\beta}}$ układu sterowania realizującego zadanie typu ,podążaj do celu”

Fig. 9. a) The signal $a_{B}$, b) the control signals of the trajectory generating layer $u_{T v}$ and $u_{T \dot{\beta}}$, c) the signals $u_{O v}$ and $u_{O \dot{\beta}}$ of the control system realising the ,obstacle avoiding” task, d) the signals $u_{G v}$ and $u_{G \dot{\beta}}$ of the control system realising the ,goal seeking” task 
Jednocześnie sygnały sterowania behawioralnego typu OA zmieniają swoją wartość, wartość $u_{O v}$ maleje, co powoduje zmniejszenie prędkości p. A WMR, natomiast wartość $u_{o \dot{\beta}}$ jest ,duża” dodatnia, co powoduje realizację manewru ominięcia przeszkody. Odległość do przeszkód nie ma wpływu na wartości sygnałów sterowania behawioralnego typu GS. W czasie $t>30$ [s] WMR znajduje się w pobliżu celu, zgodnie z przyjętą bazą reguł rozmytego koordynatora sterowań behawioralnych realizowane jest jedynie zadanie typu GS.

$\mathrm{Na}$ podstawie sygnałów sterowania warstwy planowania trajektorii ruchu $u_{T v}$ i $u_{T \dot{\beta}}$, zgodnie z zależnością (5), były obliczane zadane wartości prędkości kątowych kół 1 i $2, z_{d 2[1]}$ i $z_{d 2[2]}$, a na ich podstawie pozostałe zadane parametry kątowe ruchu kół napędzających. Przebiegi wartości zadanych $\left(z_{d 2[1]}, z_{d 2[2]}\right)$ i zrealizowanych $\left(z_{2[1]}, z_{2[2]}\right)$ prędkości kątowych obrotu kół napędzających 1 i 2 przedstawiono odpowiednio na rys. 10.a i 10.b.
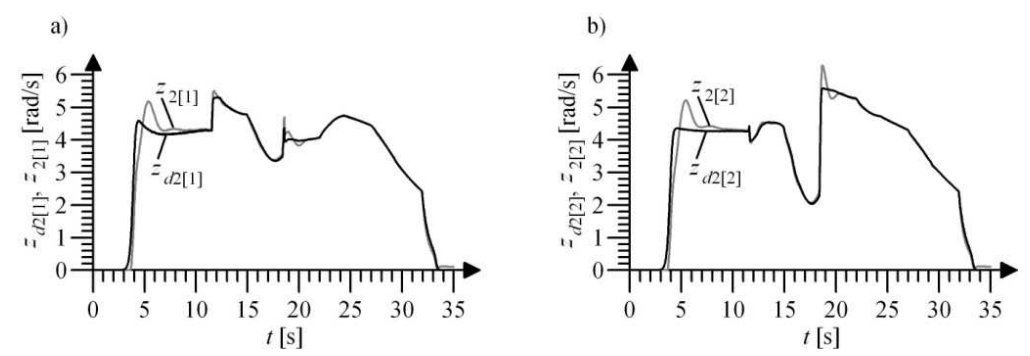

Rys. 10. a) Wartość zadanej $z_{d 2[1]}$ i zrealizowanej $z_{2[1]}$ prędkości kątowej koła

1 , b) wartość zadanej $z_{d 2[2]}$ i zrealizowanej $z_{2[2]}$ prędkości kątowej koła 2

Fig. 10. a) Value of the set $z_{d 2[1]}$ and realised $z_{2[1]}$ angular velocity of the wheel

$1, \mathrm{~b})$ value of the set $z_{d 2[2]}$ and realised $z_{2[2]}$ angular velocity of the wheel 2

Jednocześnie wygenerowane zadane parametry ruchu były przekazywane do warstwy sterowania ruchem nadążnym w celu obliczenia sygnałów sterowania zespołami napędowymi w celu realizacji trajektorii. Przebiegi całkowitych sygnałów sterowania ruchem nadążnym $u_{[1]}$ i $u_{[2]}$ przedstawiono na rys. 11.a. Zgodnie z przyjętym prawem sterowania (9), składają się one z sygnałów sterowania generowanych przez strukturę aktor-krytyk, $u_{\mathrm{A}[1]}$ i $u_{\mathrm{A}[2]}$, przedstawionych na rys. 11.b, sygnałów sterowania regulatora $\mathrm{PD}, u_{\mathrm{PD}[1]} \mathrm{i} u_{\mathrm{PD}[2]}$ (rys. 11.c), sygnałów sterowania nadzorującego, $u_{\mathrm{S}[1]}$ i $u_{\mathrm{S}[2]}$, oraz dodatkowych sygnałów sterowania $u_{\mathrm{E}[1]}$ i $u_{\mathrm{E}[2]}$, przedstawionych na rys. 11.d. W początkowej fazie ruchu, rozpędzaniu, można zauważyć dominujący udział sygnałów sterowania generowanych przez regulator PD oraz dodatkowych sygnałów sterowania $u_{\mathrm{E}[1]}$ i $u_{\mathrm{E}[2]} \mathrm{W}$ wartości całkowitych sygnałów sterowania. Jest to wynik zastosowania najmniej korzystnego przypadku zerowych wartości wag początkowych w NN struktury 
aktor-krytyk, co można interpretować jako brak wiedzy na temat dynamiki sterowanego obiektu zawartej $\mathrm{w}$ wagach $\mathrm{NN}$. W kolejnych etapach ruchu, ze względu na proces adaptacji wag NN prowadzony on-line, sygnały sterowania struktury aktor-krytyk przejmują dominującą rolę w generowanych całkowitych sygnałach sterowania, a sygnały sterowania generowane przez regulator PD są redukowane do wartości bliskich zero. Przebiegi wartości błędów nadążania kąta obrotu $e_{1[1]}$ oraz prędkości kątowej $e_{2[1]}$ koła 1 przedstawiono na rys. 12.a, analogicznie błędy nadążania koła 2 na rys. 12.b. W początkowej fazie ruchu, gdy proces adaptacji wag NN rozpoczyna się, błędy nadążania są największe, co wynika z dominującej roli sygnałów sterowania regulatora PD w całkowitych sygnałach sterowania. W kolejnych etapach ruchu, gdy sygnały sterowania członu kompensującego nieliniowości obiektu, zrealizowanego w formie struktury aktor-krytyk, przejmują dominującą rolę w sterowaniach całkowitych ruchem nadążnym, błędy nadążania są redukowane do wartości bliskich zero. Wartości błędów nadążania pozostają ograniczone w trakcie testu numerycznego.
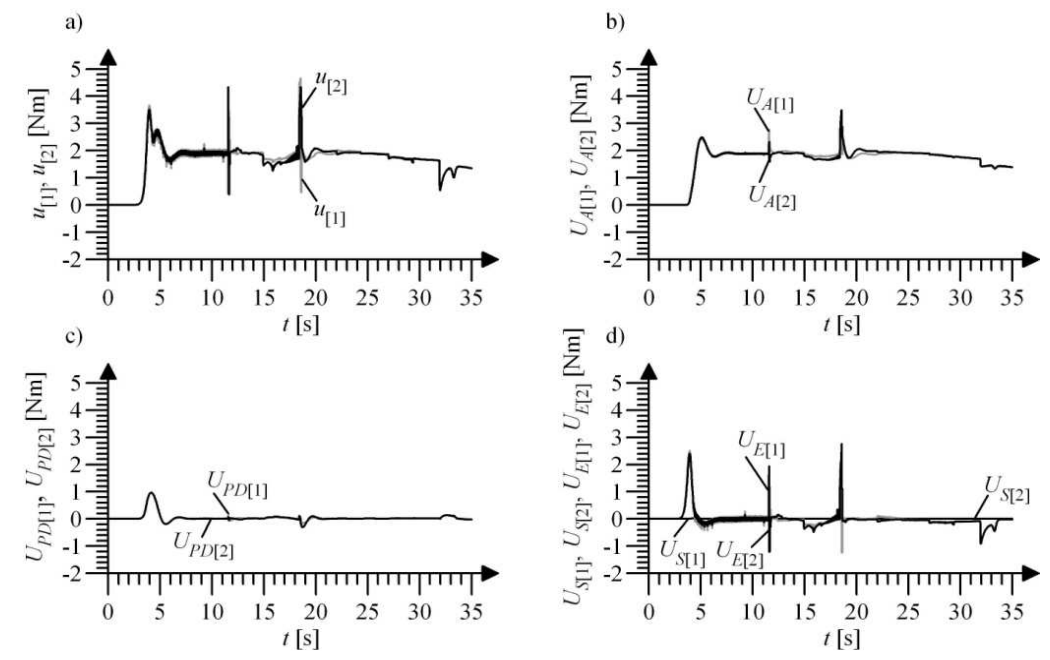

Rys. 11. a) Wartości całkowitych sygnałów sterowania nadążnego $u_{[1]}$ i $u_{[2]}$, b) wartości sygnałów sterowania $\mathrm{NN}$ aktora $U_{A[1]}$ i $U_{A[2]}, \mathbf{U}_{A}=-\frac{1}{h} \mathbf{M} \mathbf{u}_{A}$, c) wartości sygnałów sterowania regulatora PD $U_{P D[1]}$ i $U_{P D[2]}$, d) wartości sygnałów sterowania $U_{E[1]}$ i $U_{E[2]}$ oraz sygnałów sterowania nadzorującego $U_{S[1]}$ i $U_{S[2]}$

Fig. 11. a) Values of total tracking control signals $u_{[1]}$ and $u_{[2]}$, b) values of actor's NNs control signals $U_{A[1]}$ and $\left.U_{A[2]}, \mathbf{U}_{A}=-\frac{1}{h} \mathbf{M} \mathbf{u}_{A}, \mathrm{c}\right)$ values of PD control signals $U_{P D[1]}$ and $\left.U_{P D[2]}, \mathrm{d}\right)$ values of control signals $U_{E[1]}$ and $U_{E[2]}$ and supervisory control signals $U_{S[1]}$ and $U_{S[2]}$ 

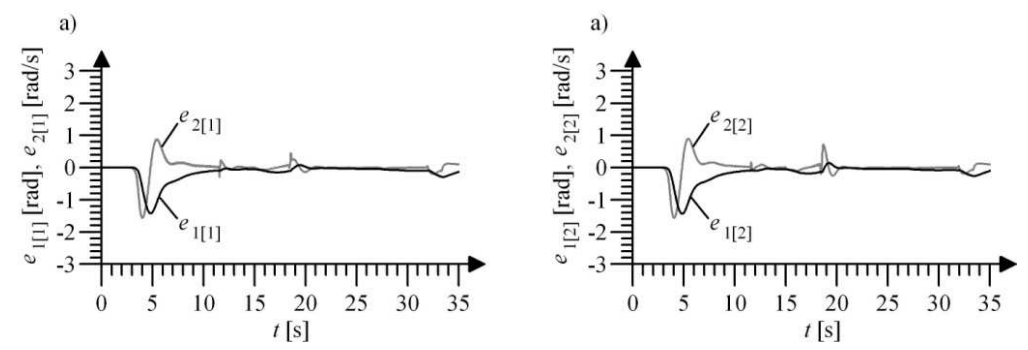

Rys. 12. a) Wartości błędów nadążania koła $1, e_{1[1]}$ i $e_{2[1]}$, b) wartości błędów nadążania koła $2, e_{1[2]}$ i $e_{2[2]}$

Fig. 12. a) Values of tracking errors of the first wheel, $e_{1[1]}$ and $\left.e_{2[1]}, \mathrm{b}\right)$ values of tracking errors of the second wheel, $e_{1[2]}$ and $e_{2[2]}$

\section{Podsumowanie}

Przedstawiono hierarchiczny układ sterowania ruchem WMR zbudowanych $\mathrm{z}$ dwóch warstw. Warstwa nadrzędna generuje trajektorię ruchu WMR w złożonym zadaniu typu GSOA. Została ona zrealizowana z zastosowaniem metod sztucznej inteligencji w formie pięciu FLS. Jest zorganizowana w formie trzech struktur, z których pierwsza składa się z dwóch FLS i generuje sygnały sterowania behawioralnego $\mathrm{w}$ zadaniu typu OA, na podstawie sygnałów z zamodelowanego układu sensorycznego WMR. Druga ze struktur generuje sygnały sterowania behawioralnego $\mathrm{w}$ zadaniu typu GS, również została zrealizowana w formie dwóch FLS. Trzecia ze struktur, składająca się z jednego FLS, generuje sygnał koordynujący sterowania behawioralne typu OA i GS, w zależności od odległości do celu i warunków środowiska, w celu realizacji złożonego zadania typu GSOA. Drugą, podrzędną warstwę hierarchicznego układu sterowania stanowi neuronowy algorytm sterowania ruchem nadążnym, zrealizowany z zastosowaniem struktury ADP w konfiguracji DHP. Algorytm DHP składa się z dwóch struktur adaptacyjnych: aktora i krytyka, zrealizowanych w formie NN typu RVFL, w których zastosowano sigmoidalne bipolarne funkcje aktywacji neuronów. Zaproponowany algorytm sterowania poprawnie generuje i realizuje trajektorię ruchu WMR w złożonym zadaniu typu GSOA, co potwierdzono przeprowadzonymi testami numerycznymi. Poprawna realizacja trajektorii ruchu do wybranych punktów nie jest możliwa z zastosowaniem pojedynczych sterowań behawioralnych typu OA lub GS, a jedynie poprzez ich połączenie. Zastosowanie FLS w algorytmach sterowania behawioralnego i rozmytym koordynatorze sterowań behawioralnych umożliwia planowanie sposobu generowania trajektorii ruchu na podstawie wiedzy eksperta. Zastosowanie algorytmów DHP w warstwie realizacji ruchu umożliwia uzyskanie wymaganej jakości realizacji ruchu. 


\section{Literatura}

[1] Arkin R.C.: Behavior-based robotics, MIT Press, Cambridge 1998.

[2] Borenstein J., Koren Y.: Real-time obstacle avoidance for fast mobile robots, IEEE Trans. Systems Man. Cybernetics, 19 (1989) 1179-1187.

[3] Burghardt A.: Implementation of kohonen network in behavioral control of the amigobot wheeled mobile robot, Mechanics Mechanical Eng., 12 (2008) 337-347.

[4] Faihimi F.: Autonomous robots. Modeling, path planning, and control, Springer, New York 2009.

[5] Giergiel M.J., Hendzel Z., Żylski W.: Modelowanie i sterowanie mobilnych robotów kołowych, PWN, Warszawa 2002.

[6] Giergiel J., Żylski W.: Description of motion of a mobile robot by Maggie's equations, J. Theor. Appl. Mech., 43 (2005) 511-521.

[7] Hendzel Z.: Fuzzy reactive control of wheeled mobile robot, J. Theor. Appl. Mech., 42 (2004) 503-517.

[8] Hendzel Z., Burghardt A.: Rozmyte sterowanie odruchowe elementarnymi zachowaniami mobilnego robota, PAK, 11 (2004) 23-25.

[9] Hendzel Z., Szuster M.: Discrete model-based adaptive critic designs in wheeled mobile robot control, Lecture Notes Artificial Intelligence, 6114 (2010) 264-271.

[10] Hendzel Z., Szuster M.: Discrete neural dynamic programming in wheeled mobile robot control, Communic. Nonlinear Sci.Num. Simulation, 16 (2011) 2355-2362.

[11] Hendzel Z., Szuster M.: Neuronowe programowanie dynamiczne w sterowaniu behawioralnym mobilnym robotem kołowym, Acta Mech. Automat., 5 (2011) 2836.

[12] Maaref H., Barret C.: Sensor-based navigation of a mobile robot in an indoor environment, Robotics Autonomous Systems, 38 (2002) 1-18.

[13] Millan J.: Reinforcement learning of goal-directed obstacle-avoiding reaction strategies in an autonomous mobile robot, Robotics Autonomous Systems, 15 (1995) 275-299.

[14] Prokhorov D.V., Wunsch D.C.: Adaptive critic designs, IEEE Trans. Neural Networks, 8 (1997) 997-1007.

[15] Powell W.B.: Approximate dynamic programming: solving the curses of dimensionality, Willey, New Jersey 2007.

[16] Sarkar S., Shome S.N., Nandy S.: An intelligent algorithm for the path planning of autonomous mobile robot for dynamic environment, Communic. Computer Infor. Sci., 103 (2010) 202-209.

[17] Si J., Barto A.G., Wunsch D.C.: Handbook of learning and approximate dynamic programming, Willey-IEEE Press, 2004.

[18] Szuster M., Hendzel Z., Burghardt A.: Fuzzy sensor-based navigation with neural tracking control of the wheeled mobile robot, Lecture Notes in Artificial Intelligence, 8468 (2014) 302-313.

[19] Szuster M: Rozmyte sterowanie behawioralne mobilnym kołowym w nieznanym środowisku, ZN PRz s. Mechanika, 86 (2014) 603-619. 


\section{PLANNING OF MOTION OF THE WHEELED MOBILE ROBOT USING FUZZY LOGIC ALGORITHMS}

\section{S u m m a r y}

In the article the hierarchical control system of the wheeled mobile robot movement in the unknown environment with static obstacles was presented. The control system consists of two layers, the path planning layer and the tracking control layer. The path planning layer generates the collision-free trajectory of the robot in the complex "goal seeking and obstacle avoiding" task. In the path planning layer fuzzy logic systems were used. The subordinate layer of the hierarchical control system was the neural tracking control algorithm. In that layer the approximate dynamic programming algorithm in the dual heuristic dynamic programming configuration was used. It was realised in a form of two structures: the actor and the critic. In both the actor and the critic structures artificial neural networks with input layer weights chosen randomly in the network initialization process and sigmoidal bipolar neuron activation functions were used. Performance evaluation of the trajectory of generating and realisation processes was verified by the series of numerical tests performed in the Matlab/Simulink computational environment, using the wheeled mobile robot emulator and the laboratory environment emulator.

Keywords: approximate dynamic programming, trajectory generator, neural networks, tracking control, fuzzy logic systems

DOI: $10.7862 / \mathrm{rm} .2015 .35$

Otrzymano/received: 4.05.2015 r.

Zaakceptowano/accepted: 16.09.2015 r. 